\title{
An interview with Anna Broinowski, director of Forbidden Lies (2007) ${ }^{1}$
}

\author{
MONIQUE ROONEY
}

Monique Rooney: Let's start by talking about how we might think of Forbidden Lies as a film about 'passing'. Your film interests me because it explores passing in a very contemporary socio-cultural context. If we think about the black person who passed for white in the pre-civil rights United States, or the Jew who passed as a gentile during the Nazi regime, then the passer in those cultural contexts is someone who escapes persecution or racial prejudice or prosecution. In your film, passing is not so much about escaping as it is about claiming an identity that turns out to be (at least partly) fraudulent. Norma Khouri/Bagain Toliopoulos presents herself as a Jordanian refugee in order to market and lend authenticity to her book about honour killings. There have been other similar cases - Helen Darville, for instance, who presented herself as Ukrainian to sell her book about the Holocaust; there's also J. T. LeRoy/Laura Albert, the subject of an essay in this journal issue.

Anna Broinowski: We have a couple in Australia too.

MR: Yes, Helen Darville/Demidenko...

AB: Paul R. Radley, Leon Carmen, who passed himself off as Aboriginal woman Wanda Koolmatrie - and, of course, Ern Malley.

$M R$ : So what do you make of Norma's role in this context? Do you see her as a passer? Why is her identity fraud successful and marketable? How can presenting yourself as a 'refugee' who has been victimised be an empowering thing?

$A B$ : She is the classic misery memoirist, in that it was her victim status that gave her the glamour and the fame, and to understand Norma you need to understand the environment that allowed her to flourish, and it was...two things: one was that she is of the Jerry Springer generation, so this is a generation that cashes in on public misery. The importance of what you have suffered increases with the number of people who know about it. So the more famously you can declare

1 Interview conducted 15 May 2009. 
your suffering, the more of a celebrity you become. It's a badge. And she's very much an American in that way - she sees nothing wrong in telling as many people as possible what she went through.

$M R$ : And her story is in many ways a rags-to-riches tale.

$A B$ : And of course it's all a lie - we'll get on to that. So there's that environment - a telegenic kind of culture that was totally geared up for exposing people like Norma, and shedding tears and making money out of the story. Then there is the environment of the build-up towards the Iraq invasion. So the Norma Khouri identity that Norma Bagain Toliopoulos constructed for herself was constructed in that period just before 9/11 and just before the Iraq war.

$M R$ : She had impeccable timing.

$A B$ : And it was a time in which there was an absolute explosion of Western interest in the Middle East. And the publishers were very much at the forefront of people trying to cash in on that. So there were a slew of misery memoirs featuring repressed-looking burqa-clad women on the covers - a kind of Middle Eastern kitsch Mills and Boon culture. And it wasn't so much the real Middle East, as 'Middle East Inc.', which is like a Western commodified, packageable, saleable image of the Middle East that Western readers were hungry to know about. Why? Because George Bush, one of the lines he was pushing at the time was, 'We will go in there to liberate their women.' And because there were a whole lot of middle-class readers in the West-America and Australia and elsewhere - who were feeling guilty about the idea that we should go and kill people and throw bombs on them, it assuaged their guilt to feel that somehow there was a feminist motivation behind this invasion, to free these repressed women from these tyrannical, misogynistic, barbaric, backwards Arab males.

$M R$ : Yes, and it's a rhetoric that can also be deployed to justify the 'liberation' process. That is, in the logic of a George W. Bush, the freeing of Jordanian women can be represented as the ultimate goal of a liberal democracy.

AB: Exactly. So Norma's book Forbidden Love completely cashed in on that. The characters in Forbidden Love are not realistic. They are archetypes. Dalia is the beautiful, repressed woman who can't even leave the house without being accompanied by her brother, and of course gets stabbed 12 times by her father and brothers when it is discovered she is having an illicit love affair with a Christian man. Yes, Dalia was Muslim, he was Christian. The men are uniformly - apart from the lover Michael, the Christian, who is a cheesy kind of hero, an upstanding fine soldier and good Christian, who loves Dalia and all they did is kiss, they didn't even fuck - apart from him, all the men are brutal, tyrannical, two-dimensional and exactly what the West had come to believe was the truth about Arab men. Now it was a complete construct and Norma cashed 
in on it by then passing herself off as the victim of this tale, who was running to the West to tell the world, to avenge her best friend's death by telling the world about this awful thing that was happening in the Middle East - as if only in the Middle East are there honour killings against women. And Norma the thirty-five-year-old, cheesecloth-wearing, make-up-free Jordanian virgin went on a five-star junket tour courtesy of Random House and Transworld and Simon \& Schuster - three huge names in publishing - through the UK, America and Australia, who become complicit in promoting this vision of the Middle East. And all you have to do is look at the cover of Forbidden Love- - that's what she was passing herself off as.

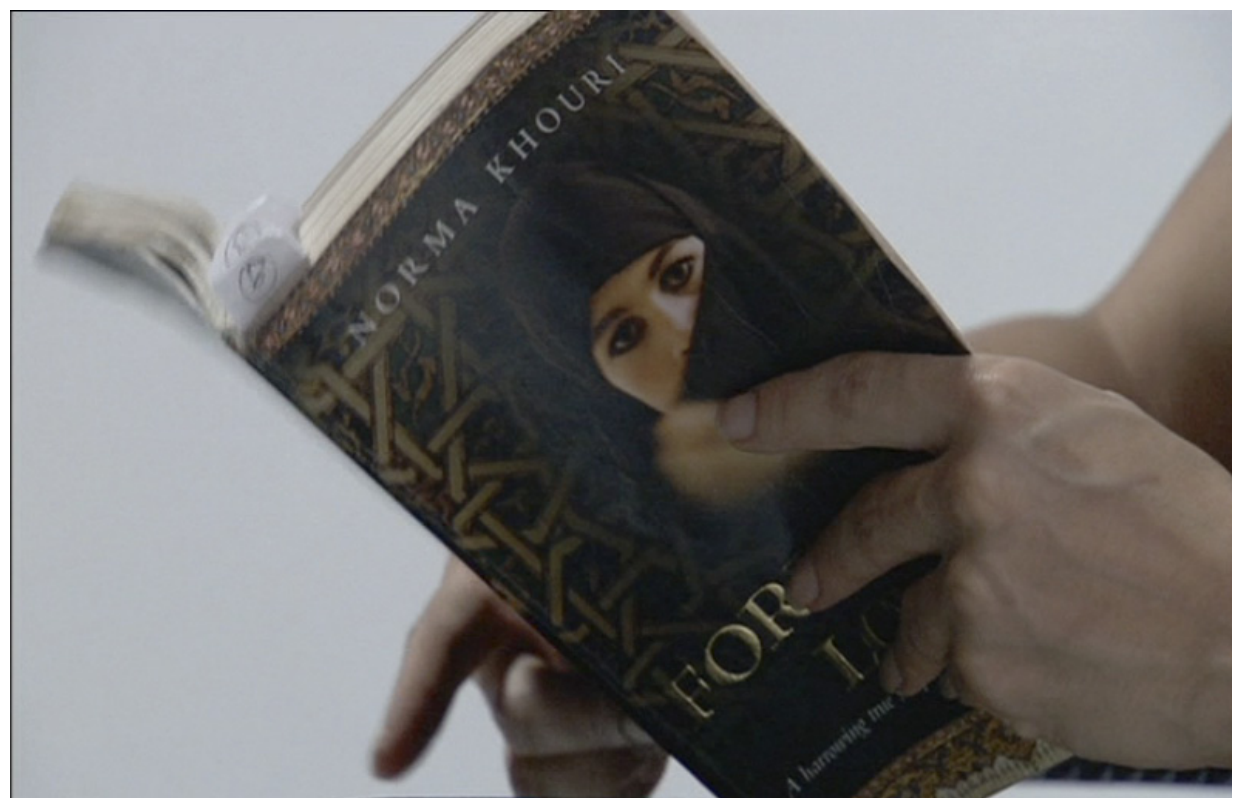

$M R$ : That's interesting - that is, that Norma was passing as a victim given that what your film exposes, to me anyway, is not a victim but Norma as this manipulative, conniving opportunist; and she's also a performer in the film, she manages to keep her act up right through to the end. It's almost as if what we are faced with in the film is a Norma who can't be honest and she keeps the lying up in a way that is quite skilful and in a way that keeps the viewer guessing, keeps you wanting to know. It seemed to me, too, that she knows how to play a part through a kind of mirroring process; it's as if she's holding up a mirror to her viewer/reader, constructing an image that she knows we want to see, such as the West's image of Jordan. What really impressed me about the film was how forthright you as the director were; I loved the scenes for instance when you said, 'Come on, Norma, I know you're lying.' I wonder then if you could talk about your role as a film-maker here and how you see your own professional boundaries in relation to your filmed subject. At what point do you decide to push and where do you pull back? Is there a kind of a dance going on? 
$A B$ : There is - and it's very much the female version of the Frank Abegnale biopic Catch Me If You Can, which, incidentally, is Norma's favourite movie. It's a mental chess game, which I made literal in one scene and had us actually playing a game of chess, because that was really the metaphor for our relationship. We like each other - we still like each other - but we don't trust each other at all, and that's actually one of the reasons we like each other because it's scintillating to be in each other's company, it's a fascinating game that we play. It is all about not trusting each other but it's also a battle of wits.

$M R$ : Did you find her threatening at times?

$A B$ : No, because I realised early on that Norma's style, while it's dissembling and mellifluous, it's not violent. I only feared for my safety with Norma once and after that I realised I was safe with her. But what you've unearthed is a minefield of ethical theory in documentary, which is the relationship between subject and film-maker.

MR: Which in some ways doubles the relationship between author and reader.

AB: Janet Malcolm's book The Journalist and the Murderer is a touchstone for me, because really what she says at the very beginning is that if any journalist is honest with themselves they'll admit that they are lying to their subject, that they make the subject think that they are going to recreate the subject's true story, but in fact all writers are using the subject as material, or fodder, for their own take on the frailty of human life. And there's another saying I'm very fond of which is 'The art of a good documentary portrait is to gain your subject's trust, and then betray them'. And in Norma's case it was doubly twisted because I had to gain her trust and then allow her to betray me. I realised that the key to Norma was the fact that she would betray me. So when I say that to audiences, I mean this in a facetious way; it's like an Oscar Wildean thing, it's meant to be a bit of a joke, a provocative statement. In San Francisco, there was a whole bunch of old-guard documentary film-makers who still subscribe to the 'direct cinema' approach to film-making, who didn't like me talking in this way at all. Direct cinema is basically the idea that the film-maker must be completely invisible, that they must hide their presence, they must have no ego, they must not intrude on the narrative, they must just use the camera as a recorder, as a notebook, just to objectively capture reality. And there's a kind of moral superiority that goes with that attitude, which is 'how dare we intrude on reality with our egos, we are bigger than that'. Of course, it's a complete conceit.

$M R$ : Because it assumes an impossibly neutral or supremely detached position?

$A B$ : It's impossible. If you look at any of the films by the practitioners of direct cinema - such as Maysles, Coppel, Wiseman-it's completely constructed, because in order to create the semblance of truth, the technical tricks involved 
are quite complex. You have to have cutaways that you shoot later, you have to deliberately make sure the sound is crappy to convey a sense of authenticity. It's just as constructed as what I did. So anyway, I offended a lot of people with my approach in Forbidden Lies, because what I decided to do was just fly in the face of all that and say, listen, we are now post-Big Brother, post-reality TV, YouTube. All audiences understand whenever they see a piece of footage that the person in that footage - unless it's a hidden camera - is aware of the camera. Therefore, why not use all the tricks that we use, but let the audience be aware of them? They are sophisticated enough now to appreciate that if you're going to trick them, and then show them how you did it, they like that, that's refreshing. So from the very beginning the presence of the camera was always acknowledged. And you can see it from the very opening shot - it begins with a film crewand Norma's awareness of the camera was always acknowledged, it had to be, because she's a performer.

$M R$ : And you've got those great scenes where she's lying on the bed playing with the digital camera, performing her own role as a performer, self-mythologiser and self-dramatiser. This is interesting to think about vis-a-vis the passer-a figure who (to a greater or lesser degree) wants to play around with but also evade her own public visibility. The passer is, in this sense, a shape-shifter, a trickster figure.

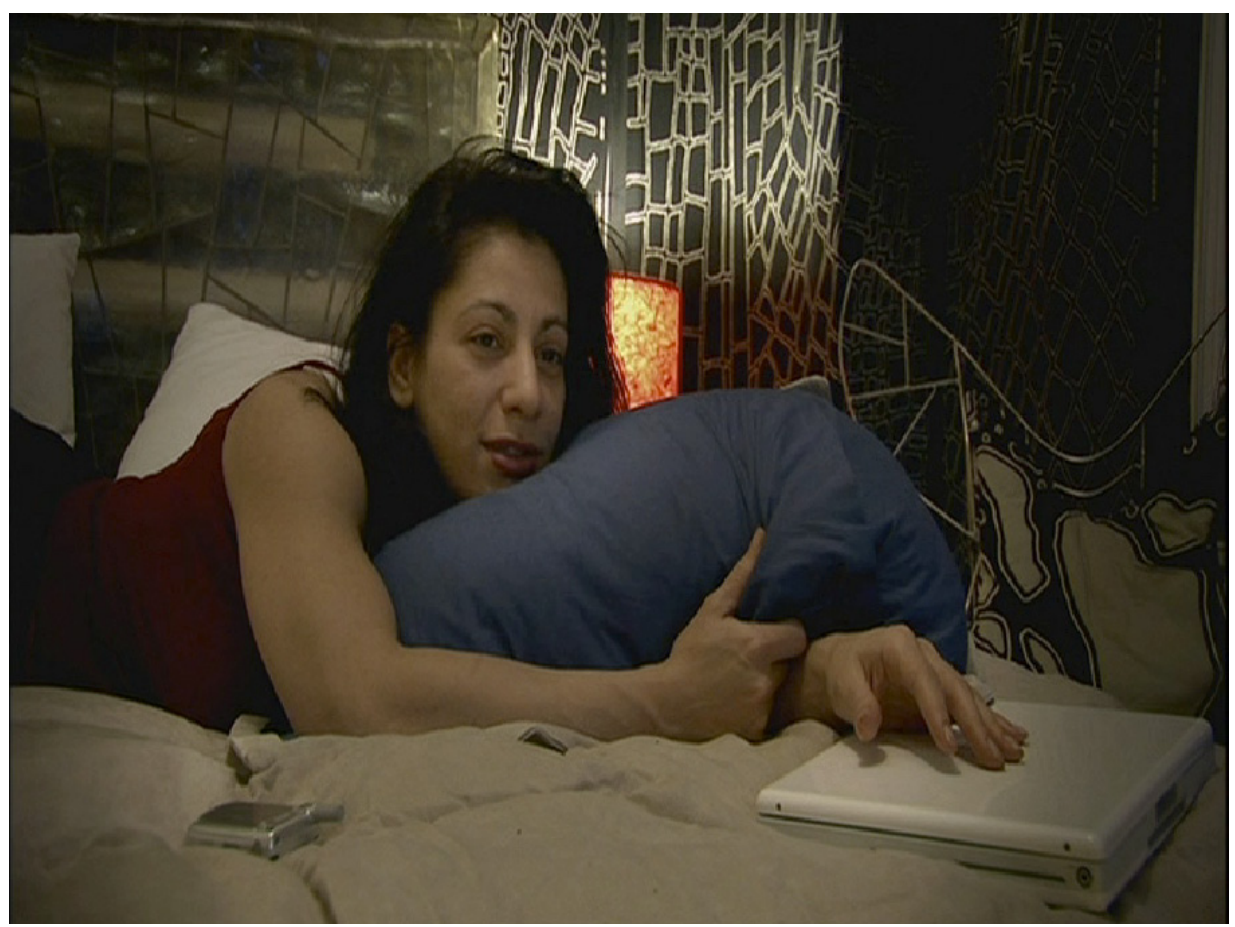


$A B$ : Norma is a consummate performer, she is a Scheherazade of the digital age, she constantly spins stories to stave off her own execution. And yes, in one sense, in Forbidden Lies the roles of con artist and film-maker are one and the same. I have to finally lie to her to get her to tell the truth; and all the way through while I was filming her, as you can see in several shots, she's directing her own little film.

$M R$ : A film within a film.

$A B$ : A film within a film, which becomes part of the film when halfway through the edit there I was with 200 hours of footage, scratching my head in despair with the editor saying, 'We've got parallel Normas; we've got the likeable, believable pleasant Norma, who's basically 90 per cent of the time presented herself to my camera. And then we've got the scheming, evil, manipulative, confabulist, who the FBI has talked about, the journalists have talked about, and the Chicago prosecutor has talked about. And that Norma has cleverly avoided being captured by my camera. What are we going to do, because we know that these are the two sides to her, but we don't have footage of her evil twin.' And then halfway through the edit this tiny little digital tape arrives from Chicago, from Norma, and it says 'For Anna-not for the film'. And it's that wonderful moment in the film where she's actually filming herself, she's with her so-called bodyguard and she's drunk, and she's gloating about how she lied to me and got away with it. After I watched it, I rang her and said, 'Listen, Norma, you've got to let me use it', because I always tried to be honest with her in the hope it would rub off on her. And she giggled and said 'just take out the bits where I call you ugly and you can use it'. So I did, but the thing about that tape that's really interesting is that it's got jump cuts all the way through it - now they're not my jump cuts, they're hers. They're her jump cuts, right down to the moment where she repeats like this. In other words, this is a wonderful moment where the film-maker becomes the con artist and the con artist becomes the filmmaker. So for me those roles you talk about, these roles we were playing-I was playing the role of victim and film-maker, she was playing the role of con artist and star-were interchangeable. Toward the end, who was directing who and who was conning who? Because I did end up conning Norma. And she did end up directing me.

MR: I find that fascinating, particularly in terms of the role of Malcolm Knox, the Australian journalist who originally exposed Norma. In an interview on ABC radio's Bookshow with Ramona Koval [see < http://www.abc.net.au/rn/ bookshow/stories/2009/2553257.htm>l, he talked about his involvement in the Norma Khouri case and what it meant for him not just as an exposure of a fraud. In fact, Knox now seems to see this hoax as having some kind of ethical outcome in that it exposed sexual violence in Jordan, albeit Norma's very partial version of that. Knox discussed the relationship between fabrication and truth 
telling and suggested that Forbidden Love can be credited for making the debate more visible in the media. What interested me about Knox's interview is the way in which it provoked his own questioning of what truth is and even his own confession. At one stage, he confessed to being a liar. I guess what all this suggests to me is a cultural fascination with the passer, as a trickster figure, as someone who we look at because we want to know, we want to find out, we want to solve a riddle. But we also want to know something about ourselves. What the case of someone like Norma does is get us to confess or get us to explore some fear that we have. The passer, in other words, can be understood as someone who incites further discourse, someone who sets off a series of other confessions related to the ubiquity of lies/dissemblances/fabrications, whatever you want to call it.

$A B$ : When you deal with a pathological liar like Norma you're tainted simply by association, you feel dirty, it does rub off. And you find yourself secondguessing everyone, not just Norma, but everyone; what is their ulterior motive? You end up not trusting anyone. And it was quite a disturbing experience, it sent me half-mad. I recorded a director's diary, which is in the DVD extras... [interruption].

$M R$ : We were talking about the relationship between passing, truth telling and confession.

$A B$ : Yes, the camera is a wonderful confessional tool. There's a fabulous film-maker called Jean Rouche who was flying in direct opposition to the practitioners of direct cinema in the Seventies and Sixties, who actually said that the camera was a catalyst and the director should embrace rather than try to hide its presence because it gets things out of people that they wouldn't normally ever say in real life. You get extraordinary versions of people, things they don't normally present to the world, when you point a camera at them. And Errol Morris talks about the same thing. He has this three-minute rule; he says if you let anyone talk to a camera for three minutes just about themselves, uninterrupted, you will discover that everyone is mad. And with Norma, similarly, there was this wonderful organic effortless relationship between me and her whenever I had the camera on her. She has a performer's instinct; it's intricate and beautifully developed. She is as good as any actress. And that sort of ability to perform can only come from someone who's been doing it for a very, very long time. Which would indicate that perhaps there was some kind of abuse that happened to her when she was much younger that forced her to practise being someone she wasn't, or to hide a secret by acting. My DOP [director of photography], Kathryn Millis, picked up on just how brilliant she is in front of the camera. We were filming that scene where she's listening to the FBI tape and we were filming a close-up and we had her hand and the tape recorder on a window sill, and without even needing to be told, Norma knew somehow that the camera was 
in a close up on her hand, rather than a wide shot of her whole body, and she just did this, she just stroked the machine with one finger, without being told. And Kathryn couldn't believe it; she said, 'This is the sort of bravura touch that Meryl Streep would give you.'

$M R$ : Yes, it's precisely her 'performer's instinct' as you say. This is key to what's fascinating about her in the film. There is an interesting construction in the film of Norma as a consummate performer but also as someone who is alert, constantly reading, aware of your responses and reacting to that. There's something very instinctive going on there.

$A B$ : But when you say 'passing', she's not a schemer, not a cold, Machiavellian long-term analytical planner at all. She's an instinctive, improvising animal, which is why she gets caught out-because she improvises on the fly. She doesn't plan her lies years in advance; she tends to make them up on the spot, massaging them according to the situation. The only way I was able to catch her out was because I was armed with 12 months of rushes, so this made me a lot better protected than any of her other victims because I could actually go back and see her lying to me 12 months earlier; I could see her contradicting stories she'd subsequently told me. She wasn't bargaining [on] that. And so when I say she's instinctive, she just does it naturally, like any great actress, she believes it as she does it. There's not a third eye operating with Norma, which is sitting above her looking at herself and thinking, 'how am I doing and is that person getting it?'. It's far more organic than that. In the DVD extras, Miranda Otto, the actress, analysed Norma on camera and said her performance was subtle enough to win an Oscar. As Miranda says, 'all acting is bluffing', but Norma seems to feel her bluffs, which is what makes her so good.

$M R$ : What about the moments, then, in the film when she almost confesses to having lied?

$A B$ : There's an amazing moment...I tried and tried to get her to break down and confess on camera. I gave her so many opportunities. And the closest we ever got - and you really can't tell from the words but you can tell from the body language - is the very last interview I ever filmed with her. In the movie, it's about 10 minutes before the end. She's sitting in a dark hotel room just staring at the camera, she's saying, 'No-one was listening, no-one was listening.' She's talking about how she went in and said to the FBI, 'Here I am, you want mehere I am.' She had sent them a letter saying 'I ripped off Mary'. And I said, 'Why the hell did you do that?', and she said, 'No-one was listening.' And it's this amazing pause and she actually, literally holds her hand up to her ear. And I'm convinced that that was the closest Norma ever came to sharing with us what's really in her soul. She's not a psychopath in that she does know how to have empathy and she does know how to relate to people. She is a sociopath, in 
that she will opportunistically cash in on her charm to get what she wants from people, which isn't just money - it's attention, approval, and even love. And sure, maybe she'll feel a little bit of remorse for the people that are hurt in the process - I sometimes wonder if she does actually; I don't know, but she's not psychopathic. She's not that evil.

$M R$ : To go back to the point I was making earlier, the fascination with that kind of sociopathic behaviour perhaps suggests something in us, so that Norma does enact that mirroring role.

$A B$ : Like any good dissembler, she feeds back to us the stories we want to hear. I was also trying to trust her as a film-maker, because I had to... at the beginning, I really believed her, but then she turned the tables on me. I turned up for our first interview not believing her, telling the crew to hide their equipment, that she was not to be trusted and within eight hours of interviewing her, the sound recordist had fallen in love with her, the DOP wanted to buy her book and she'd convinced me that she was telling the truth and that if I took her to Jordan she would prove that the Western media had conducted this merciless witch-hunt, they were out to get her, and she wasn't a hoax author, but they'd buried her because they liked the idea of the conniving femme fatale. And I believed that because that turned on all my feminist buttons. At the beginning I believed her because I thought what person in their right mind would promise to go all the way to Jordan to prove their story on camera if they couldn't deliver? But then halfway through when I realised that she was probably going to con me too, I had to hide my frustration behind the film-maker's facade. I had to 'pass' as a film-maker: remain objective, shelve my resentment and my personal disappointment (although I didn't do it very successfully) and keep asking her questions.

$M R$ : When you say you're passing as a film-maker, do you mean passing as one who can take up a neutral position?

$A B$ : Yes-I was pretending to be neutral.

$M R$ : So there is a point at which that kind of film-making is useful, even though your feminist instincts or your experimental drives as a director might warn you against that?

$A B$ : Sure. But then it gets much more complex than that, because I did end up being very honest with her and saying, 'Look, you haven't told us the truth in Jordan, you've just led us on a goose chase', and she giggled and said, 'Yeah, I made it pretty hard for you, didn't I?' And I said, 'Why did you do that?' And there's a long scene that's not in the film — part of it's in the DVD extraswhere she said, 'Because I didn't trust you. You can't expect me to trust you if you don't trust me. And why would I tell you the truth if I don't trust you; 
you're just going to hurt these people.' And that was very clever of her, because that went straight to my Achilles heel. I hate as a film-maker to feel like I'm exploiting people or treating them badly or trying to cash in on their story to make a name for myself. This is like anathema to me - and she knew that. And any great con artist can do that. They will read you, they will find out where you're most vulnerable and they'll play that for all it's worth. I've seen her do that with people. And she did it with me. I made her watch the Truman Capote film - the one with Phillip Seymour Hoffman - and in there there's this wonderful scene where Capote won't tell Perry Smith, the murderer subject of his book, that the book is called In Cold Blood, because if he does that Perry will realise that Capote doesn't think he is innocent. And I made her watch that movie before we went to Jordan and said, 'I don't want to be Capote with you, I want to tell you what I'm doing. By the way, the title of the film is Forbidden Lies - what do you think?' She twisted that on me, she said 'and then you made me watch Capote and you wouldn't even tell me the title of the film'. It was a complete lie - both confusing and hurtful.

$M R$ : From memory, one of the things that film foregrounds is Capote's adept interviewing technique. For instance, he allegedly did not need to use a tape recorder. He claimed to have something like 99 per cent memory retention, so he could remember everything and write it later, and he argued that that's how he won the trust of his subjects.

$A B$ : Norma told me things off camera that she didn't tell me on camera, at the very beginning. But looking back on it she was doing that deliberately, so that I would then see those as the truffles that I had to dig up on film. And sure enough, by the end of the filming process, I had managed to get her to confess things on camera. She planted the seed at the very beginning about her father abusing her and told me not to use it. By the end of the shoot, with her full cooperation, it was in the film.

$M R$ : I saw those moments as part of the film's compassion for Norma. Compassion? Is that the right word to use?

$A B$ : We needed a redemptive ending. After Jordan, it was clear that she'd conned us too, but I didn't want to bury her the way the media had already. I just thought that would be the same old story, and also I liked her. So I rang her up - and this is where the Jerry Springer thing comes in, but it's also where the symbiotic interchangeability of the roles of film-maker and con artist comes in. Because I rang her up and said, 'Norma, we need a redemptive ending. We need something to send the audience the message that we care about you, because right now they're not going to. You've just completely spun me bullshit from whoa to go. What do I do with this? Have a think about talking about your father. Have a think about it. And please let us film you again, because otherwise 
I just have no choice, I'm going to have to end on a rather bleak note- -you're just an out-and-out liar.' And she, amazingly, agreed to let us come to Chicago and film her again. And that's when that stuff all came out. The father, the white room, the moment where I confront her with her own lie. And I'm happy to go on the record. This is the one time I lied to her. At the time, she trotted out that article that said that 'Dalia is Ghada Ahbed. This is the real Dalia.' I already knew that that couldn't be the real Dalia because I'd triple-checked with Rana Husseini and she said 'that woman, yes she was killed, but she was killed eight months after Norma had written two-thirds of the book, so how could she be Dalia?'. I knew that and the only time that I stopped being honest with Norma and became a con artist myself-in other words, lied to her - was when we came back to Chicago to do that last shoot and we were in the white room; I made her believe that I believed that Ghada was Dalia, so that I could finally confront her on camera, on the spot, and say, 'Norma, I know this isn't true.' Now I'm not proud of that, but I couldn't get her to reveal that she was a liar any other way. So there you go. Is that ethical? I don't know. And then at the very end, when we finally showed her the film when it was finished in Chicago and recorded the DVD commentary together, Norma and I sat on the couch like this and chain smoked and drank wine and watched the film and talked about it. When that moment came up and I said, 'There Norma, I tricked you there. You thought I believed in Ghada, but I didn't. I tricked you.' She said, 'Oh no you didn't. I already knew. I just wanted you to have your little moment.' So, the web continues to spin. It's a möbius strip of deceit. And I kind of felt better when she said that, I felt better about lying to her. She knew anyway, so maybe I wasn't as evil as I thought. I loved her for that.

$M R$ : To return to the father and the way in which the film brings in the story of Norma's possible childhood abuse. Is this about audience compassion? Or is it a narrative that gives the viewer a framework for understanding Norma?

$A B$ : Certainly it's about giving the audience a chance to at least understand Norma on some level even if they don't condone what she's done. But it's also dangerously close to couch psychology.

$M R$ : So it is just another storyline? But you said earlier that you're sure that there was something there.

$A B$ : I'm sure that there is. I've met her mother, who wouldn't agree to be in the film, and I strongly feel that it's the mother not the father who was abusive. I don't even know in retrospect if that really was her father. It could have been her uncle; I have no idea.

$M R$ : Smoke and mirrors. 
$A B$ : Yeah, more smoke and mirrors. Some friendly relative who agreed to play a part. The body language of both Norma and [her supposed] father is very disturbing in that sequence. OK. Sure, I'm writing it off in a way, because every documentary maker when they're doing a bio, they tend to sneak in a bit of amateur psychology. It's a Hollywood thing too- the flashback, 'when I was a little girl'. And suddenly everything makes sense.

$M R$ : This is what I loved about the film - not only its self-consciousness about the role of film technology in producing narrative and identity fabrications or hoaxes, but the way it drew on Hollywood melodrama. It seemed to me the film had an awareness of the formulas, the plots that we watch on screen but that we also use in everyday life.

$A B$ : Audiences are ready for this. They have been fed so many genres now, they are so savvy, they are more visually fluent than they ever have been, because we're dealing more and more in images. You might as well play, because they understand it now. The fourth wall is bullshit; no-one suspends their disbelief anymore, whether it's drama or doco. Unfortunately, people still trust the veracity of documentary more than they do drama; I don't think they should. Documentary is just as deceitful and constructed. And I'm deeply suspicious of documentary film-makers that still try to pretend that they're not there, because the minute you point a camera at something you're putting your point of view across. And to me it's the ultimate lie to the audience. It's saying, 'Hey, you're watching real life here, and there's no camera crew 5 metres from the character's face. This is really happening.' Of course, someone's crying, but they know the camera's there. Let's just acknowledge it for God's sake. It makes it far more interesting, unless you want to just shoot everything with hidden cameras, which is ethically very suspect.

$M R$ : This is a good point at which to talk about the film you've started working on.

$A B$ : It's probably a bit dangerous to write about that now, until we have the budget. Let's put it this way. Drama and documentary more and more are borrowing from each other and the nature of what truth is for an audience is continuing to change and...ever since $9 / 11$ we have a new Zeitgeist that embraces the art of dissembling and spin, simply because the politicians have made it legitimate.

MR: Former Australian Prime Minister John Howard certainly did.

$A B$ : And Bush. So audiences are more sophisticated than ever before and, as a result, film-makers are forced to find far more interesting and knowing takes on truth and integrity. And you know the drama thing is now often produced for the stars. Stars are now celebrities in magazines, so people don't go and 
see an Angelina Jolie movie to really believe that she's this repressed Jewish wife or 1920s mother or whatever; they go to see what she looks like in that hat compared to how she looked in Who magazine last weekend. No-one is suspending their disbelief.

$M R$ : You said that as a film-maker you're interested in women and female subjects. I found the film compelling for that reason as well - given that you're a female director who is trying to unlock the mystery of this evasive woman. One of the characters that intrigued me is that of Rachel Richardson, Norma's friend, who takes her in and looks after her children while Norma is hopping about and evading the law. Some time after your film was released, Rachel Richardson was exposed as a welfare cheat. So, she is another example of a woman who is there on camera, there for us to believe in as someone who can expose Norma, but then later, it becomes evident that Rachel is herself passing, she's not simply an innocent bystander who has fallen into Norma's trap. It suggests that Rachel's relationship to Norma was more complicated than it appears. Would you say that your fascination is with the female subject on film, with the woman as performer? I could take us back to some feminist theory here, to the idea that women are expected to perform, to enact a masquerade, in a way that men are not.

$A B$ : There's this old saying in Hollywood that 'there are no new stories, just new ways of telling them'. And to me that is absolute rubbish. That comes from a long-held, 104-year-old history of patriarchal storytelling about men as heroes and women as adjuncts or lovers or whores - very much a male-driven plot. And they're right there are no new 'straight' male stories anymore. There aren't; they've all been done. What haven't been done are the female stories. And so that's why I make films about women. I do it selfishly. I believe that that is what makes audiences excited because they see new stories on screen. And yes, in the male-driven narrative tradition of film, women have had to pass as male versions of what women should be, so that the wife is the cheesy, cheesecake, cardboard cut-out good wife and the mistress is always the vixen. And you know these archetypes; they're there in every film and every TV series you've ever seen. That's breaking down now, because more and more women are coming in and now we are finally discovering roles in which women are not passing for what men feel they should be, but being themselves in their own right. Now my fascination with Norma is that she is still very much a woman in a man's world, in that she was passing herself off as an archetype that men would understand and want to protect. That is, the poor oppressed Jordanian woman on the run from bloodthirsty Muslim extremists. But then the other Norma, the one that she revealed to me, was very much the woman herself. I mean, I'm a female director, so she...did try to play victim with me, and brought out all my protective instincts and I felt like the bloke sometimes and wanted to look after 
her. But that fell apart very quickly and she ended up having to be much more honest about herself. Which is 'yes, I'm going to lie, and I'm going to have fun with it', and it was a much more provocative game, a duel, that we then played. And Rachel, similarly, you get something more honest from these women when they become the main characters in your film, as opposed to people who have to relate to men who drive the narrative.

MR: What's at the heart of the film - but also perhaps the book-for me, is not a woman passing herself off as a male version of what women are, but a woman looking for another woman, even if that woman is a fiction. So Dalia may not exist, but she also does exist, because Norma spent all this time creating her.

$A B$ : I made a list the other day; there were actually four different Dalias during the course of the shoot that she presented us with. They're not all in the film, but there's Chicago Dalia. So for a while she had me convinced that D. was based on a woman who was in Chicago, an Arab woman, burnt to death while making coffee by her Muslim father in a basement. Then there was cousin Dalia, Norma's cousin, who she reveals at the end of the film-you know, 'this woman was abused'. Then there's Ghada Ahbed, who really was honour killed in Jordan, and then there's Dalia in the book. And in fact there're five Dalias, because the fifth Dalia, which is entirely possible, is actually Norma. So what's she writing in that woman? What version of herself is she treating as a cipher that she has to idolise and then let go of? Interestingly, in the language of flowers, the dahlia signifies treachery - although that's a different spelling. And I said that to Norma and she just giggled and said, 'Oh really, that's amazing.'

$M R$ : But there's the instinctive performer again. It's a Norma who is being hidden from you, in a way.

$A B$ : Look, she's a human being, and it's all too easy to write her off as some of the psychiatrists did that I spoke to-as a narcissistic sociopath with psychopathic tendencies. No, she's damaged. There's something deeply human and to this day I do feel that she wasn't lying about everything. If there's one thing she's absolutely genuine about, she really did want to try and do something about honour crimes. She genuinely did. But because she was who she was, she couldn't help but do it the wrong way. As she said herself, 'I did the right book the wrong way for the right reasons.'

$M R$ : Or the right way?

$A B$ : I don't know about that. I think it's outrageous the number of lies she told about Jordan and the way she wrote about that country was reprehensible.

$M R$ : Perhaps not the right way in a moral sense, but if she had told it another way, would she have got the readership and the film-maker and the exposure? 
$A B$ : No, of course not, but has the film really helped her? I doubt it. She keeps sending me snippy little emails: 'So, what's this you've said in this interview?' We're constantly emailing each other about it. I don't think she's that happy that it's come out in America. But it's good she's known as Norma Khouri in the film, because that's not how she passes herself off in real life in America. She's Norma Bagain. So she's protected and that makes me feel better. Because I don't care what she's done if she's alive and trying to survive and raise her kids, that doesn't justify, that doesn't give me an excuse to bury her further. I hope ultimately I've made a film that makes audiences not so much judge Norma, as recognise that the media, the publishers and even me the film-maker have all been complicit in constructing the environment which had enabled her to thrive. 